Dean A. McManus

University of Washington - Seattle, Washington USA

\title{
WHO WILL TEACH OUR CHILDREN ABOUT THE OCEAN?
}

What a magnificent opportunity for ocean sciences education! Or so it seemed. It came with the findings reported by the National Center for Education Statistics in 1999 by William J. Hussar (NCES 1999026) that approximately 2 million additional $\mathrm{K}-12$ teachers would be needed in the U.S. by 2008-09. Some of these additional teachers would replace retiring teachers and some would be needed for increasing student enrollments. The magnificent opportunity arose when this need was viewed against the background of the National Science Education Standards of 1996, which had assigned earth science the same educational value as the life sciences and physical sciences. The need for teachers to teach earth science, including oceanography, therefore, would be greater than ever. And the number of science teachers had already been increasing. In fact, between 1990 and 1998 the number of teachers increased more in the earth sciences than in physics, chemistry, or biology. But who are these teachers?

Surveys of teacher qualifications and student achievement report the positive correlation that one would expect. Among other factors, the better the teacher knows the science content and understands the scientific concepts, the more proficient the students are in science. Because of this finding, reports the Council of Chief State School Officers, during the 1990s many states developed policies on teacher certification that require teachers to have more knowledge and understanding of the science they will be teaching. By the year 2000, for secondary certification in science (grades $7-12), 19$ states required teachers to have a major in science and another 13 required either a major or a minor. (Eighteen states, consequently, did not require either a major or minor in science.) The Council notes that by 1999 more than three-fourths of all secondary science teachers already had a major or minor in science. Encouraging though this general information appears to be, the results of the America Geological Institute's (AGI) synthesis and survey of $\mathrm{K}-12$ earth science education in all 50 states in 2001 is troubling. (Oceanography is included under the certification for teaching earth science.)
One question AGI asked was "What percentage of high school teachers whose main assignment is earth science are certified in the subject?" Twenty states did not answer the question, a circumstance that gives one pause. In only 6 of the remaining 30 states were more than $50 \%$ of the earth science teachers certified in earth science. Only 6 ! In 14 states less than $25 \%$ of the teachers were certified in earth science. These numbers do not bode well for the existence of many classrooms in which a confident teacher, knowledgeable in the facts, methods, and concepts of earth science, can effectively engage and enhance students' learning of the subject beyond a particular module or lesson, regardless of his or her dedication to teaching. But even certified earth science teachers do not necessarily have a degree in oceanography.

In K-12 education, earth science includes geology, atmospheric science (meteorology), and astronomy, as well as oceanography. A person with a baccalaureate degree in any one of these four sciences might need only a few credits in the other three for certification to teach earth science. Peterson's Guide to undergraduate majors lists 571 colleges and universities in the U.S. that offer baccalaureate degrees in geology and its associated sciences. Only 37 institutions offer the degree in oceanography, which is probably a misleadingly low number, because "marine science" is not listed as a major and institutions offering that major are absent from the oceanography list. Nevertheless, few institutions offer an oceanography or marine science baccalaureate degree. The degree in atmospheric science is offered by 61 institutions and that in astronomy by 98 . On the basis of these numbers alone one might assume that most teachers with a baccalaureate degree in earth science received the degree in geology or another solid earth science with perhaps only a course or two in oceanography. Nevertheless, at least they would have studied some aspects of the ocean in their geology curriculum, such as plate tectonics and sedimentary processes, but they probably were not introduced to concepts in physical, chemical, and biological oceanography. Only the teachers with a baccalaureate degree in 
oceanography or marine science would have studied all four aspects of the ocean. An obvious question, therefore, is whether undergraduate oceanography and marine science departments even encourage their students to consider teaching as a career.

To find out, I asked seven of these departments if their undergraduate program includes "K-12 teacher" as a career option. One department did not respond. Of the remaining six, five do offer teaching as a career option. That such a high proportion in this unscientific sample offer this option is encouraging for the future of the science, but all five are still trying to resolve problems associated with this endeavor. Two are exploring a procedure that the geology departments in their institutions already have in place. Two are grappling with the problems of adding the course requirements of the College of Education to their own very full curriculum of an interdisciplinary science. The additions can lengthen the time to degree, an outcome that lessens the appeal of these programs to students. Nevertheless, these departments are actively developing their programs and by holding career workshops, inviting speakers, adding a teaching lab to required science courses, or partnering with a College of Education, even when it is at another university, they are encouraging students to explore this option. Although the problems of developing a teaching career option are local, varying with the policies of the science and education units and the certification policies of the state, these departments might well benefit from a forum in which they could discuss goals, methods, obstacles, and solutions.

Having a major or minor in earth science is not the only way to obtain secondary certification with respect to subject area. The other ways are defined by specific credits in science, courses set by colleges or universities, and state-approved standards for teachers. According to the AGI survey, in almost half the 50 states, the high school subject area certification requirement for teaching earth science is 20-60 credits of earth science, with a requirement of 24-36 credits being far and away the most common. Those credits must cover geology, atmospheric science (meteorology), and astronomy, as well as oceanography, and possibly some required specific courses, such as both physical geology and environmental geology. As a result, these 24-36 credits may translate into a teacher having had only Oceanography 101 as an oceanography course. Nevertheless, this teacher is still likely to have majored in a science, but which one?

According to the Council of Chief State School Officers' statistics, in 1998 there were more than 3 times as many biology teachers as earth science teachers in grades 9-12 and half again as many chemistry teachers as earth science teachers. Further, according to the most recent National Science Foundation (NSF) data (1996), almost 20 times as many baccalaureate degrees were granted in biology as in earth science and almost 4 times as many in the physical sciences as in earth sci- ence. Therefore the probability is high that many teachers teaching earth science majored in biology or chemistry and are teaching earth science with only the credits of an introductory oceanography course for non-scientists. How many of the basic concepts of oceanography are found in a biology or chemistry curriculum? How many examples used in biology and chemistry labs are set in the ocean? How often are ocean processes described in biology or chemistry textbooks? The earth science teacher with an oceanography degree who is mentoring his or her biologist and chemist colleagues might answer those questions: Not many! Not many! Not often!

To be sure, there is help for teachers who are teaching about the ocean with little knowledge and understanding of oceanography. Professional organizations such as the National Marine Educators Association and several federal agencies offer professional development workshops or short courses, either in person or on line. Many innovative teaching materials are available as physical materials, CD-ROMs, or Web-based materials. Interns, fellowship holders, and scientists come to the classrooms or take teachers to sea. These and other support efforts should be increased. But teachers have little time to learn on their own and are usually poorly supported for professional development. In addition, these teachers lack knowledge of the context of oceanography that one learns by studying that science. (Teachers who know the science and understand the concepts, other factors being equal, better enable students to learn it.) All these conditions make the education of preservice teachers in undergraduate oceanography departments critical to underpinning $\mathrm{K}-12$ ocean sciences education and providing subject-area mentors. In addition, the breadth of the oceanography baccalaureate degree program can prepare a preservice teacher to teach biology, chemistry, or physics, as well as earth science. I submit to you that this is whom we want to teach our children about the ocean-children who will become our future undergraduate and graduate students, future oceanographers, future employees in diverse fields, future voting citizens. Let us take time from our research and graduate teaching to ask those undergraduate departments that are educating future teachers: How may we help you-to help us all? 